\title{
Management and Development of an Assessment Tool in Predicting Competencies of Oil and Gas On-Shore Contractor Workers in Sarawak
}

Sazali Saini, Mohd Ibrani Shahrimin Adam Assim, Omar Faruqi Marzuki, Yasmin Yaccob

To Link this Article: http://dx.doi.org/10.6007/IJARBSS/v11-i12/11746 DOI:10.6007/IJARBSS/v11-i12/11746

Received: 08 October 2021, Revised: 11 November 2021, Accepted: 29 November 2021

Published Online: 16 December 2021

In-Text Citation: (Saini et al., 2021)

To Cite this Article: Saini, S., Assim, M. I. S. A., Marzuki, O. F., \& Yaccob, Y. (2021). Management and Development of an Assessment Tool in Predicting Competencies of Oil and Gas On-Shore Contractor Workers in Sarawak. International Journal of Academic Research in Business and Social Sciences, 11(12), 18-33.

\section{Copyright: (c) 2021 The Author(s)}

Published by Human Resource Management Academic Research Society (www.hrmars.com) This article is published under the Creative Commons Attribution (CC BY 4.0) license. Anyone may reproduce, distribute, translate and create derivative works of this article (for both commercial and non0-commercial purposes), subject to full attribution to the original publication and authors. The full terms of this license may be seen at: http://creativecommons.org/licences/by/4.0/legalcode

Vol. 11, No. 12, 2021, Pg. $18-33$ 


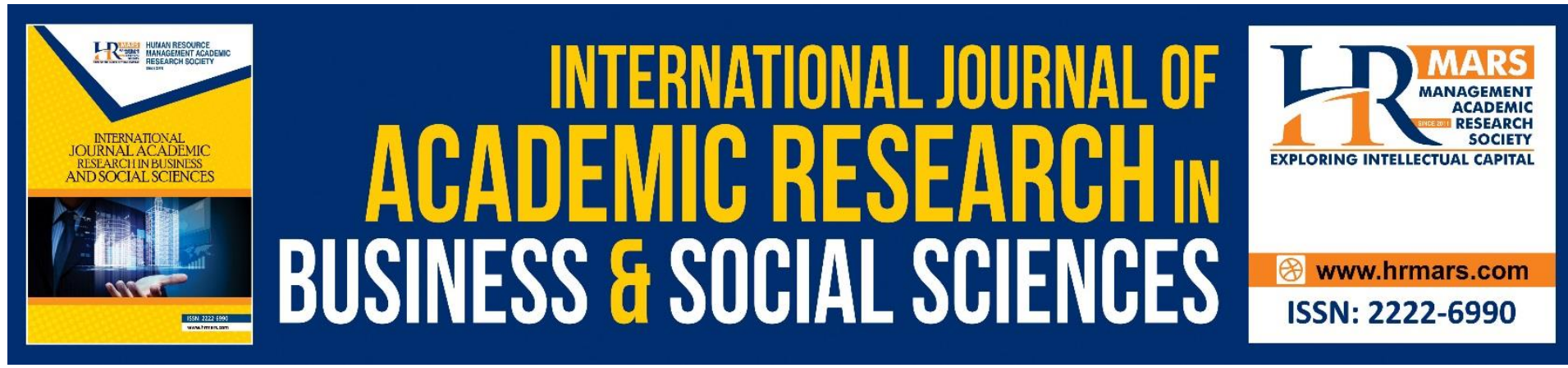

\title{
Management and Development of an Assessment Tool in Predicting Competencies of Oil and Gas On-Shore Contractor Workers in Sarawak
}

\section{Sazali Saini ${ }^{1}$, Mohd Ibrani Shahrimin Adam Assim², Omar Faruqi Marzuki ${ }^{1}$, Yasmin Yaccob²}

${ }^{1}$ Department of Science and Technology, Faculty of Humanities, Management and Science, Universiti Putra Malaysia Bintulu Campus, Sarawak, Malaysia, ${ }^{2}$ Department of Social Science and Management, Faculty of Humanities, Management and Science, Universiti Putra

Malaysia Bintulu Campus, Sarawak, Malaysia

Corresponding Email: sazali.saini@gmail.com

\begin{abstract}
One active site that is involved with onshore oil and gas activity is Bintulu, which is in Borneo, Sarawak. There is an average of 1800 contractor workers at the site with a size of 276 hectares, an average of 462 Permit-To-Work (PTW) released daily. The site recorded 1 fatality case in every 5 years cycle since 2009. This trend shows that serious attention needs to be addressed, especially on the contractor worker selection process. Due to this, worker's competency working in this industry needs to be strengthened as part of the element in Health, Safety, and Environment Management System (HSEMS) requirement to ensure sustainable and safe operation of the plant as it contributes to HSE performance of the organization. The objectives of this study involve assessing contractor's HSE competency and HSE attitude working in the oil and gas industry in Sarawak, develop a comprehensive assessment tool to measure worker's competency, and propose a specific syllabus for potential workers to work in the oil and gas industry. Hence, a pilot survey has been conducted to assess 88 contractor worker's HSE competencies. A quantitative approach via a Likert scale questionnaire was used to collect the data. The pilot survey results show that education level, experience, and competency played key important roles in HSE. Based on the pilot survey findings and literature review related to competency assessment for the workforce in oil and gas, furthering this study will be able to develop an algorithm for the assessment of contractor worker's HSE competency in the oil and gas industry in Sarawak.

Keywords: Competency, Contract Workers, Oil and Gas Industry, Assessment Tool, On-Shore, Sarawak.
\end{abstract}

\section{Introduction}

The oil and gas industry are one of the most dangerous and high-risk activities which contribute to critical economic activity for Malaysia. One of the active sites that involve in this activity is Bintulu, which is in the Tropics as shown in Figure 1. There is a frequent major 
incident happened around the world involving this industry, example tank fire, explosion, and gas leak. Numerous fatal and non-fatal injuries occur from various activities carried out in maintaining and operating the facilities. These included working at height, critical lifting, working with high voltage equipment, working in $\mathrm{H} 2 \mathrm{~S}$ area, handling hazardous chemicals, exposure to radioactive material, and others. Due to the complexities of the technology, hazard, and risk exposure in oil and gas industries, specific competencies and skills are required by personnel before they enter the industries and performed the job safely. It is highlighted that incident are often complex involving multiple causes which include the level of personnel competency (Bhusari et al., 2020).

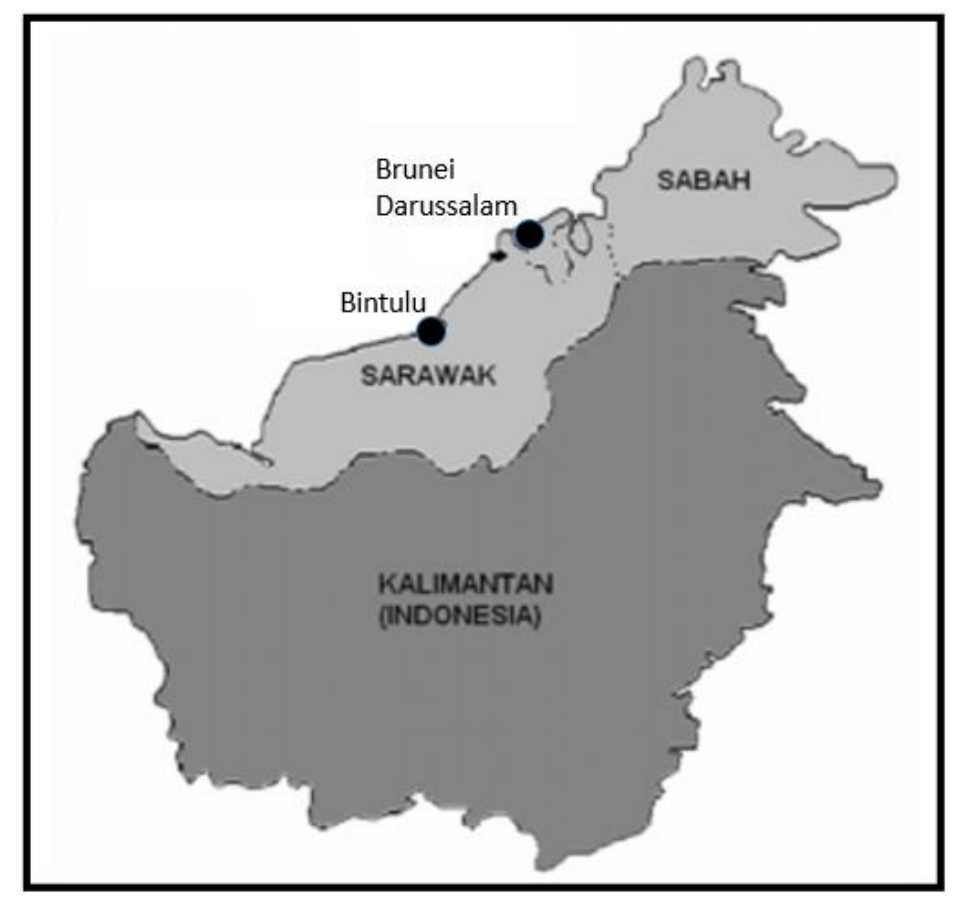

Figure 1: Borneo Map

There are several issues affecting the competency of contractor workers. One of them is a subcontracting mode that has been introduced by international major oil and gas players in their overseas operations. In the early 1980s, Alain Wisner coined - along with his team of the Conservatoire National des Arts et Métiers in France - the concept of Anthrop technological islands to refer to the way to manage safety in the branches of multinational companies located in developing countries (Wisner, 1984). After 30 years of this publication, downsizing processes took place in organizations through outsourcing. The priority in these processes was the reduction of costs. As a result, instead of the transference of risk management technologies, what took place was the transference of riskier activities to contractors.

Whereas many reports indicated that oil and gas project failures were caused by local content issues, including a high percentage of imported raw materials, lack of qualified professionals and labor with the technical skill competency for the assignment, inadequate infrastructure, and power, etc. As new workers, adolescents are likely to be inexperienced and unfamiliar with many of the tasks required of them. The nature and organization of work are evolving, and young workers can expect to change jobs and employers many times during their working lives. These shifts will result in an increased likelihood of encountering 
new or different hazards or risk scenarios, suggesting the importance of an ongoing application of foundational occupational safety and health knowledge (Schulte et al., 2005). Moreover, most of Oil and gas facility in Borneo/Tropics falls under Major Hazard Installation $(\mathrm{MHI})$ as per DOSH regulation, which requires the industries to have effective HSEMS that helps organization to ensure safe operation of the facility as shown in Figure 2. Training and competency are one critical element/pillars that need to be in place to ensure people are being equipped with the right knowledge, skills, and experience to work in the oil and gas industries. Safety training emerged as a significant predictor of safety knowledge, workrelated injuries, and workplace accidents. Hence, this research aims to develop an assessment tool for contractor worker's HSE competency in the oil and gas industry in Borneo/Tropics (Liu et al., 2020).

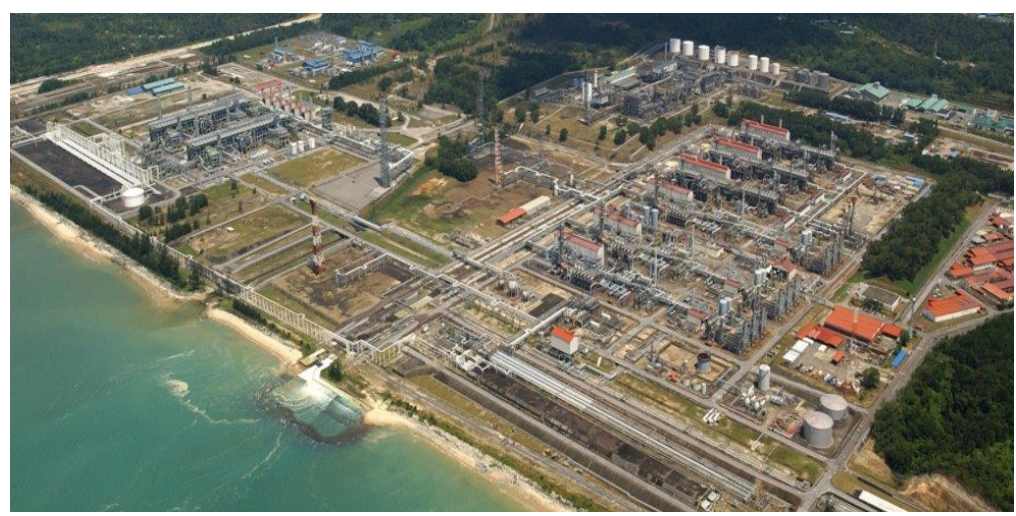

Figure 2: On-Shore Plant Facility

\section{Competency Factors}

Many factors can be taken into competency account. The terms "21st-century skills," "workreadiness skills," "job-readiness skills," and "employability skills," have become watchwords in education, business, and government. Numerous frameworks articulate the skills, knowledge, and abilities for a skilled worker in the modern economy (Partnership for 21st Century Skills, 2009; The Conference Board, Partnership for 21st Century Skills, Corporate Voices for Working Families, \& Society for Human Resource Management, 2006; U.S. Department of Labor, 2008). However, as previously noted, workplace safety and health are currently missing from many, if not most, of the current frameworks to prepare the future American workforce.

This sector is facing several workforce-related challenges and overcoming these ensures sound human resource practices, provides influential talent culture, and a more robust industry (Kanason, 2018). The growth of the case sector results in increasing demand for the trained workforce as the scenario of human resources has reached a highly competitive level (Gallardo-Gallardo et al., 2013). A series of publications have shown that people are the predominant reason for the problems (Vredenburgh, 2002; Mullen, 2004). Not only people are acknowledged as the contributing factor, but organizational factors shape the context that contributes to at-risk work behavior and human error (Papazoglou and Aneziris, 1999).

According to the results of the correlation analysis of workers' age, the number of years of service, cognitive ability, and workability by, there was a strong correlation between workers' age and the number of years of service (Chung et al., 2015). However, there was no significant 
correlation between worker's age and cognitive function or workability. In addition, workability had a positive correlation with cognitive function, but there was no significant correlation between workability and age or number of years of service. Although it cannot be said that older workers with more experience always have higher workability, workability tends to increase as cognitive ability improves. According to a study conducted by Salthouse (1997), the positive effects of job experience can be directed towards basic cognitive processes or job performance. Nevertheless, it is worth noting from these previous studies that older workers were at least as productive as younger workers; the results for the different age groups were found to be the same in jobs demanding skill and speed.

Notably, young people frequently enter the labor force lacking even the most basic workplace safety and health knowledge and skills needed to be cognizant of the safety and health challenges and hazards they may face. The inverse relationship between age and nonfatal work injuries is a consistent association found in occupational safety and health research (Breslin et al., 2007; Laflamme and Menckel, 1995). Adolescent sensation seeking-the desire to pursue novel and intense experiences and sensations - and adolescent risk taking, especially when in the company of other young people, are commonly observed phenomena among developing youth (Spear, 2000). Moreover, when adolescents experience an absence of negative consequences when they engage in risky behavior, feelings of invulnerability may increase (Reyna and Farley, 2006). Lack of job-related knowledge, skills, and training; and lack of job control also contribute to heightened risk among younger workers, who might be less likely to recognize hazards, less likely to speak up regarding safety issues (Breslin et al. 2007; Tucker and Turner, 2013; Zakocs et al. 1998), and less aware of their legal rights as workers.

Based on the incident in the industrial, there is a causal chain of organizational conditions and human errors indicating that human-factor causes can be attributed to $70-80 \%$ of accidents in high-hazard industries (Ruzana et al., 2017). One critical factor in preventing accidents is the ability of workers to maintain an adequate understanding of their worksite situation. This means having a high level of awareness of task and environmental conditions and judging how these may change in the future to predict how the situation will develop. Possession and maintenance of good quality appear to be of particular importance in the offshore oil and gas industry, where the work is hazardous, time-pressured, and complex. A safety awareness campaign is one of the best methods and initiatives on how to educate the worker's knowledge toward safe working culture offshore. Low understanding of hazards towards workers is a key factor that leads to the incident offshore even though safety awareness campaigns have been conducted before mobilization. It is not only an awareness campaign but at the same time, the main objective is to transfer the knowledge as knowledge sharing to the workers to practice during performing their task. Apart from the campaign, training materials and deep knowledge are also important to ensure that all workers understand the dangers of their job. Ensure that every worker understands the hazards of their work will reduce the risk of harm that leads to injury and death. As we all know, workers that working in the oil and gas industry is highly equipped with high education and experience employees but lack knowledge of the issues pretending to hazard associated with the work. They only know how to carry out their work without knowing the potential hazards associated with their work that can cause injury. 
Despite the technical causes of failure, the International Atomic Energy Agency (IAEA) report on the Chernobyl disaster introduced the concept of the "safety culture" in the high consequences industry, which is a hidden factor affecting safety (Choudhry et al. 2007; Pidgeon, 1991). Culture, by definition, is a norm shared among the people, which is evolved by internal and external influences, national and regional conditions, the educational and socioeconomic background of the people (Guldenmund et al., 2006). An organization's safety culture is a norm of its commitment to both personnel and process safety. Numerous definitions of safety culture are available in the literature. Choudhry et al., (2007) comprehensively addressed those definitions in a review article. The crux of all definitions is presented by the Advisory Committee on the Safety of Nuclear Installations as "The Safety Culture of an organization is the product of individual and group values, attitudes, perceptions, competencies, and patterns of behavior that determine the commitment to, and the style and proficiency of, an organization's health and safety management" (Advisory Committee on the Safety of Nuclear Installations, 1993. The safety culture itself is not a tangible concept and is difficult to measure (Mannan \& Lees 2012). Safety culture assessment requires the selection of an appropriate model, data gathering, and techniques to obtain measurable and repeatable assessment results (Maddin and Shanks, 2016). Substantial numbers of models have been presented since the introduction of the concept of safety culture (Ahmadi et al., 2014; Maddin and Shanks, 2016).

Moreover, the negative relationship between HSEMS and workplace accidents and injuries show that the existing HSEMS are either ineffective or lack the acceptable safety standards to control hazard exposures in the industry. PETRONAS has developed a technical standard to assist the contractor in identifying competency requirements to engage workers in their activity as shown in Figure 3.

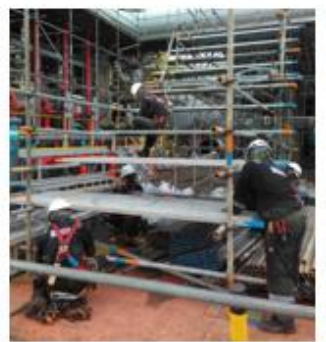

Erection of scaffolding as temporary platform

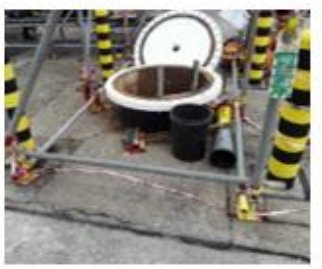

Confined space activity to do inspection work

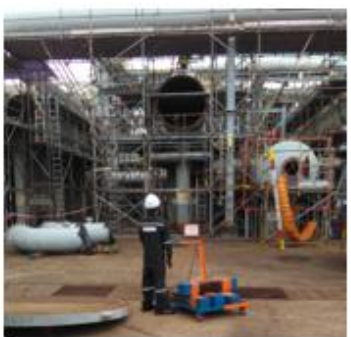

Manual handling to move material/equipment at site

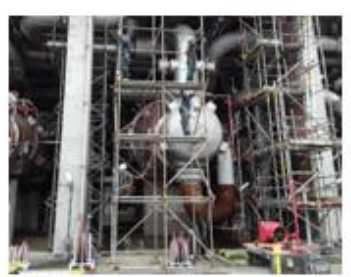

Erection of scaffold more than $5 \mathrm{~m}$ height for paint job

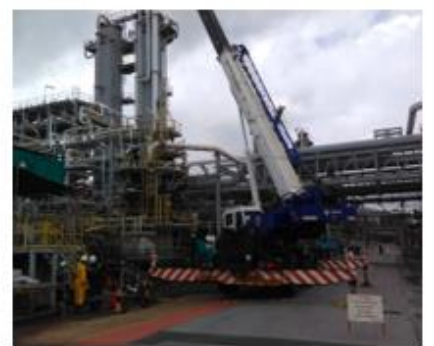

Critical lifting activity over live line with load more than 1 tonne

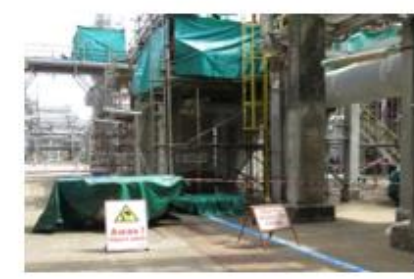

Hot work activity at height

Figure 3: Worker activity in Oil and Gas Industry

\section{Assessment Tools}

Assessment tools are a technique used to measure potential worker's qualifications, competency, experiences, and safety aptitude related to onshore oil and gas activities. These assessment tools are required in ensuring the organization or company can determine and 
confirm that they are engaging the workforce with competent and right safety behavior to work in a hazardous environment. Past researchers have proposed several methods related to working competency as shown in Table 1.

Table 1: Assessment methods and tools

\begin{tabular}{|c|c|c|c|}
\hline No & Research & $\begin{array}{l}\text { Parameter } \\
\text { covered }\end{array}$ & Method \\
\hline 1 & $\begin{array}{lr}\text { Seo et al., } & \text { (2015). } \\
\text { Analyzing } & \text { safety } \\
\text { behaviors } & \text { of } \\
\text { temporary } & \\
\text { construction } & \text { workers } \\
\text { using } & \text { structural } \\
\text { equation r modeling } \\
\text { (SEM). }\end{array}$ & $\begin{array}{ll}\text { 1. Safety } \\
\text { Behavior } \\
\text { 2. Compentecy }\end{array}$ & $\begin{array}{l}\text { Structural equation modeling (SEM) is } \\
\text { used to estimate simultaneously the } \\
\text { cause-and-effect relationship between } \\
\text { many independents' variables and } \\
\text { dependents variables. The author } \\
\text { modified the Neuroticism-Extraversion- } \\
\text { Openness Personality Inventory-Revised } \\
\text { (NE)-PI-R; Costa and McCrae 1992), } \\
\text { edited and standardized by Ahn et al., } \\
\text { (2014) for use with construction workers. } \\
\text { A questionnaire was administered and } \\
\text { analyzed using SEM. }\end{array}$ \\
\hline 2 & $\begin{array}{l}\text { Khan et al., (2015). } \\
\text { Analysis of } \\
\text { competencies, job } \\
\text { satisfaction (JS) and } \\
\text { organizational } \\
\text { commitment (OC) as } \\
\text { indicators of job } \\
\text { performance: } \\
\text { conceptual } \\
\text { framework. }\end{array}$ & $\begin{array}{l}\text { 1. Skill } \\
\text { 2. Competency } \\
\text { 3. Organization }\end{array}$ & $\begin{array}{l}\text { Proposed conceptual framework (CFW) } \\
\text { developed linking current and needed } \\
\text { competencies with JS and OC. A survey } \\
\text { method was employed to validate the } \\
\text { proposed model and to test the } \\
\text { propositions. } \\
\text { Correlation and regression analyses were } \\
\text { utilized to investigate the relationship } \\
\text { and effect of current skills on JS and OC. } \\
\text { Paired sample t-tests were applied to test } \\
\text { the different hypotheses or to discover } \\
\text { the significance of differences among } \\
\text { study constructs. }\end{array}$ \\
\hline 3 & $\begin{array}{l}\text { Russo, (2016). } \\
\text { Competency } \\
\text { Measurement Model. }\end{array}$ & $\begin{array}{l}\text { 1. Competency } \\
\text { 2. Organization } \\
\text { 3. Syllabus }\end{array}$ & $\begin{array}{l}\text { A model for the competency mapping and } \\
\text { measurement developed through } \\
\text { literature review, analyzing the } \\
\text { relationship between: } \\
\text { i. Staff and processes (Who does what) } \\
\text { ii. Processes and skill (What staff should } \\
\text { know) } \\
\text { iii. Staff and competencies (What staff } \\
\text { currently know) } \\
\text { The model can provide identification of } \\
\text { the competency's employees need to } \\
\text { improve performance in their current job }\end{array}$ \\
\hline
\end{tabular}




\begin{tabular}{|c|c|c|c|}
\hline & & & $\begin{array}{l}\text { or to prepare for other jobs via promotion } \\
\text { or transfer besides useful in a skill gap } \\
\text { analysis, the comparison between } \\
\text { available and needed competencies of } \\
\text { individuals or organizations. }\end{array}$ \\
\hline 4 & $\begin{array}{l}\text { Ismail et al., (2020). } \\
\text { Technical } \\
\text { Competency among } \\
\text { Vocational Teachers } \\
\text { in Malaysian Public } \\
\text { Skills Training } \\
\text { Institutions: } \\
\text { Measurement Model } \\
\text { Validation Using PLS- } \\
\text { SEM }\end{array}$ & $\begin{array}{l}\text { 1. Competency } \\
\text { 2. Knowledge } \\
\text { and skill }\end{array}$ & $\begin{array}{l}\text { This study is quantitative research } \\
\text { collected data through simple random } \\
\text { sampling of vocational teachers from } \\
\text { several technical programs. } \\
\text { Measurement assessments were used to } \\
\text { conduct a Partial Least Squares (PLS) } \\
\text { analysis with SmartPLS } 3.0 \text { software to } \\
\text { assess and validate the eight constructs of } \\
\text { technical competency using a reflective } \\
\text { model. }\end{array}$ \\
\hline 5 & $\begin{array}{l}\text { Kenayathulla et al., } \\
\text { (2019). } \\
\text { Gaps between } \\
\text { competence and } \\
\text { importance r of } \\
\text { employability skills: } \\
\text { evidence } \\
\text { Malaysia. }\end{array}$ & $\begin{array}{l}\text { 1. Competency } \\
\text { 2. Skill } \\
\text { 3. Interpersonal } \\
\text { skill } \\
\text { 4. Syllabus }\end{array}$ & $\begin{array}{l}\text { Stratified sampling was used to select } \\
\text { students in these hospitality programs } \\
\text { from } 22 \text { vocational colleges in Malaysia. } \\
\text { Questionnaires were distributed to } 841 \\
\text { students in five regions in Malaysia. In } \\
\text { general, the respondents spent } 30 \text { min to } \\
35 \text { min to respond to the questionnaire } \\
\text { completely. Descriptive analysis and } \\
\text { paired sample t-test were conducted to } \\
\text { analyze the data. }\end{array}$ \\
\hline 6 & $\begin{array}{l}\text { Bayram, (2019). } \\
\text { Safety Training and } \\
\text { Competence, } \\
\text { Employee } \\
\text { Participation and } \\
\text { Involvement, } \\
\text { Employee } \\
\text { Satisfaction, and } \\
\text { Safety Performance: } \\
\text { An Empirical Study on } \\
\text { Occupational Health } \\
\text { and Safety } \\
\text { Management System } \\
\text { Implementing } \\
\text { Manufacturing Firms. }\end{array}$ & $\begin{array}{l}\text { 1. Training } \\
\text { 2. Competency } \\
\text { 3. HSEMS }\end{array}$ & $\begin{array}{l}\text { A survey approach was used. To realize } \\
\text { the aim of the study, } 529 \text { OHSMS certified } \\
\text { firms operating in different industries, } \\
\text { different sizes, and different workplace } \\
\text { hazard classes in Turkey were found via } \\
\text { certification firms, the authors' social } \\
\text { network, and firm websites. }\end{array}$ \\
\hline 7 & $\begin{array}{l}\text { Held et al., (2019). } \\
\text { Training the Future } \\
\text { Workforce: } \\
\text { Workers in }\end{array}$ & $\begin{array}{l}\text { 1. Work Skill } \\
\text { 2. Competency } \\
\text { 3. Syllabus }\end{array}$ & $\begin{array}{l}\text { This study used a phenomenological } \\
\text { qualitative design consisting of individual } \\
\text { interviews with social work practitioners } \\
\text { employed on integrated health care }\end{array}$ \\
\hline
\end{tabular}




\begin{tabular}{|c|c|c|c|}
\hline & $\begin{array}{l}\text { Integrated } \\
\text { Care Settings. }\end{array}$ & & $\begin{array}{l}\text { teams. Data were collected using a survey } \\
\text { and interview method. A total of } 14 \\
\text { participants were invited to participate in } \\
\text { the study. }\end{array}$ \\
\hline 8 & $\begin{array}{l}\text { Novianti and } \\
\text { Nurlaelawati (2019). } \\
\text { Pedagogical } \\
\text { Competence } \\
\text { Development of } \\
\text { University Teachers } \\
\text { with Non-Education } \\
\text { Background: The Case } \\
\text { of a Large University } \\
\text { of Education in } \\
\text { Indonesia. }\end{array}$ & $\begin{array}{l}\text { 1. Competency } \\
\text { 2. Educational } \\
\text { Background } \\
\text { 3. Experience } \\
\text { 4. Training }\end{array}$ & $\begin{array}{l}\text { A preliminary survey of lecturer } \\
\text { pedagogical development, and } 20 \text { of } \\
\text { them joined our interviews and focus } \\
\text { group discussions conducted. At the end } \\
\text { of the study, a model of pedagogical } \\
\text { competence development based on the } \\
\text { results of the survey, interview, and } \\
\text { focus-group discussion was developed. } \\
\text { Our design was also informed by a } \\
\text { literature review on pedagogical } \\
\text { competence development, such as on the } \\
\text { techniques or methods to develop a } \\
\text { lecturer's pedagogical competence based } \\
\text { on well-established theories and previous } \\
\text { relevant studies. }\end{array}$ \\
\hline 9 & $\begin{array}{lr}\text { Suhairom et al., } \\
\text { (2019) Quality } \\
\text { culinary workforce } \\
\text { competencies for } \\
\text { sustainable career } \\
\text { development among } \\
\text { culinary } & \\
\text { professionals. } & \end{array}$ & $\begin{array}{l}\text { 1. Competency } \\
\text { 2. Interpersonal } \\
\text { skill }\end{array}$ & $\begin{array}{l}\text { Qualitative research design using } \\
\text { document analysis techniques and } \\
\text { interviews were employed to obtain } \\
\text { views within the context of Malaysian } \\
\text { culinary settings. The integration of these } \\
\text { two data sources allows the comparison } \\
\text { and triangulation of rich and relevant } \\
\text { data. The qualitative data were used to } \\
\text { form the framework of the Star-Chef } \\
\text { Competency Model, which consists of six } \\
\text { identified competency constructs. The } \\
\text { compilation of the identified competency } \\
\text { statements was fully utilized in the } \\
\text { development of the competency model } \\
\text { and is believed to be very helpful } \\
\text { guidance for culinary professionals in the } \\
\text { Malaysian hospitality industry. }\end{array}$ \\
\hline 10 & $\begin{array}{l}\text { Ferjencik \& } \\
\text { Slovackova (2014). } \\
\text { Trust Managers and } \\
\text { Respect Workmen: } \\
\text { What does it mean to } \\
\text { be competent in } \\
\text { caring about safety. }\end{array}$ & $\begin{array}{l}\text { 1. Competency } \\
\text { 2. Qualification } \\
\text { 3. Behavioral } \\
\text { Safety } \\
\text { 4. Organization } \\
\text { 5. Interpersonal } \\
\text { skill }\end{array}$ & $\begin{array}{l}\text { Generic standards developed through } \\
\text { literature review to show how } \\
\text { competence standards for caring about } \\
\text { safety may be created and applied to } \\
\text { align with European Qualification } \\
\text { Framework. The analysis procedure is } \\
\text { divided into six steps, each of them is }\end{array}$ \\
\hline
\end{tabular}




\begin{tabular}{|c|c|c|c|}
\hline & & & $\begin{array}{l}\text { investigated in an individual section of } \\
\text { this paper. }\end{array}$ \\
\hline 11 & $\begin{array}{lr}\text { Dingsdag et } & \text { al., } \\
\text { (2008). } & \\
\text { Understanding } & \text { and } \\
\text { Defining } & \text { OH\&S } \\
\text { Competency } & \text { for } \\
\text { Construction } & \text { Site } \\
\text { Positions: } & \text { Worker } \\
\text { Perceptions. } & \\
\end{array}$ & $\begin{array}{l}\text { 1. Attitude } \\
\text { 2. Perception } \\
\text { 3. HSEMS } \\
\text { 4. Organization } \\
\text { 5. Training }\end{array}$ & $\begin{array}{l}\text { A survey was administered to site-based } \\
\text { workers via contacts with primary } \\
\text { contractors. }\end{array}$ \\
\hline 12 & $\begin{array}{l}\text { Nykänen et al., } \\
\text { (2018). Enhancing } \\
\text { Safety Competencies } \\
\text { of Young Adults: A } \\
\text { Randomized Field } \\
\text { Trial (RCT). }\end{array}$ & $\begin{array}{l}\text { 1. Training } \\
\text { 2. Experience } \\
\text { 3. Skill } \\
\text { 4. Attitude } \\
\text { 5. Syllabus }\end{array}$ & $\begin{array}{l}\text { Level of awareness and propose a } \\
\text { guideline on areas of improvement were } \\
\text { identified. Prior to embarking offshore, } \\
\text { staff was exposed to a safety awareness } \\
\text { program for four weeks. After the } \\
\text { program, we started with the pretest to } \\
\text { all staff. They were posted offshore for } 6 \\
\text { weeks. Within the period, the } \\
\text { performance awareness of each staff is } \\
\text { monitored through observation and } \\
\text { interview. During the final week, the } \\
\text { posttest questionnaire was administered } \\
\text { to all staff. Two instruments were used } \\
\text { for the quantitative data collection, which } \\
\text { are the Unsafe Act Unsafe Condition } \\
\text { (UAUC) card; and Behavior Observation } \\
\text { Tool (BOT) card. Questionnaire data were } \\
\text { analyzed quantitatively. A Paired-sample } \\
\text { t-test was used for analyzing pre and post } \\
\text { result. }\end{array}$ \\
\hline
\end{tabular}

The most common parameter appears in articles related to the evaluation are:

1. Competency: (Seo et al., 2015; Khan et al., 2015; Russo 2016, Ismail et al., 2020; Kenayathulla et al., 2019; Bayram, 2019; Held et al., 2019; Novianti \& Nurlaelawati, 2019; Suhairom et al., 2019; Ferjencik \& Slovackova, 2014).

2. Skill: (Khan et al., 2015; Ismail et al., 2020; Kenayathulla et al., 2019; Held et al., 2019; Nykänen et al., 2018).

3. Training: (Bayram, 2019; Novianti \& Nurlaelawati 2019; Dingsdag et al., 2008; Nykänen et al., 2018).

4. Syllabus: (Russo 2016; Kenayathulla et al., 2019; Held et al., 2019; Nykänen et al., 2018).

Currently, there is no comprehensive tools to assess and verify potential contractor worker's competency related to HSE. In fact, the focus on the assessment and verification process must be more than one recording individual training course have been completed and the number of required jobs has been carried out. The industry has line up requirements on roles and responsibilities of contractors in providing trained and competent workers in executing their 
contract (PETRONAS). However, currently, the verification process is only limited to confirming paperwork requirements. It should go through systematic assessment and verification of the competency itself. Having a greater assurance in the quality, relevance, and current of the assessment and verification of the competence of the personnel undertaking safety-critical tasks will improve HSE performance and reduce potential incidence from happening.

\section{Pilot Study}

Following the method selected above, a survey instrument has been developed in collaboration with subject matter experts from various disciplines. 88 samples have been collected to confirm the reliability of the questionnaire. From the reliability statistics test conducted (refer Table 1), the alpha coefficient for the 2 sets of questions was found to be respectively 0.881 and 0.892 . This concludes that the items have relatively high internal consistency. A reliability coefficient of 0.7 or higher is considered "acceptable" in most social science research situations (Taber, 2018).

Table 1: Value of Alpha coefficient

\begin{tabular}{|c|c|c|c|}
\hline \multicolumn{4}{|c|}{ Case Processing Summary (Safety Behavior) } \\
\hline & & $\mathrm{N}$ & $\%$ \\
\hline \multirow{3}{*}{ Cases } & Valid & 87 & 98.9 \\
\hline & Excluded $^{a}$ & 1 & 1.1 \\
\hline & Total & 88 & 100.0 \\
\hline
\end{tabular}

Reliability Statistics (Safety Behavior)

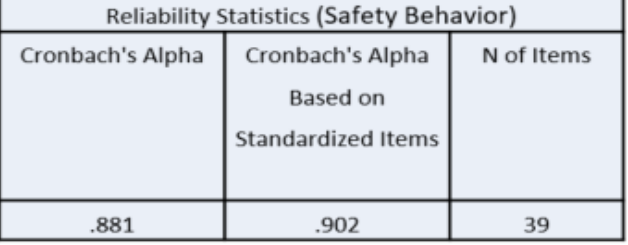

\begin{tabular}{|c|c|c|c|}
\hline \multicolumn{4}{|c|}{ Case Processing Summary (Safe System of Work) } \\
\hline & & $\mathrm{N}$ & $\%$ \\
\hline \multirow{3}{*}{ Cases } & Valid & 88 & 100.0 \\
\hline & Excluded $^{\mathrm{a}}$ & 0 & .0 \\
\hline & Total & 88 & 100.0 \\
\hline
\end{tabular}

Reliability Statistics (Safe System of Work)

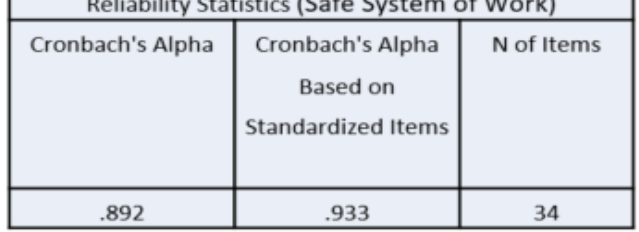

Findings from the pilot test concluded 11 areas that have signed the findings. Three Common findings that can be observed from all 11 results below. These three findings will be analyzed further upon full-scale data collection in the later stage.

Respondent's educational level is between SPM/SPMV and Diploma Level Findings are aligned with studies conducted by Salminen (2004); Breslin et al., (2007) from previous studies which shown that younger age groups are at an elevated risk of accidents at work. Inexperience, short job tenure, and type of industrial establishment can all lead to a greater risk of occupational accidents among young people (Bena et al. 2013; Breslin et al., 2007). Previous studies indicate that in upper secondary-level educations, student's knowledge and awareness of occupational safety is often limited (Salminen and Palukka 2007; Andersson et al., 2015).

Their working experience is between 0-5years and 6-10 years

These findings are aligned with studies conducted by Mullen (2004), where people may adopt unsafe work practices if the perceived positive aspects of risk-taking outweigh the potential negative aspect (risk of being injured). Previous studies have shown that young worker's risktaking orientation at work is also influenced by peer workers (Westaby and Lowe, 2005). While Breslin et al (2007) found that young workers may see injuries as 'part of the job'. The locus of control concept refers to the degree to which an individual perceives that 
the outcome of the situations they experience is under their control. Studies also have found that management commitment and involvement are key elements in achieving success in safety performance at the workplace (Langford et al., 2000; Tam et al., 2004). Young people may lack skill and training in how to appropriately respond to working practices that are unsafe (Kincl et al., 2016; Mullen, 2004), for example, found that young workers may choose not to use safety equipment or may tend to work unsafely to avoid being teased by their coworkers. Tucker and Turner (2013) in turn describe how young workers' reluctance to take action to solve safety problems can be related to an underlying fear of being fired, newcomer status, and feelings of powerlessness.

The distribution between Permanent and Contract Worker are equal

Many reports indicated that oil and gas project failures were caused by local content issues, including a high percentage of imported raw materials, lack of qualified professionals and labor with the technical skill competency for the assignment, inadequate infrastructure, and power. These shifts will result in an increased likelihood of encountering new or different hazards or risk scenarios, suggesting the importance of an ongoing application of foundational occupational safety and health knowledge (Schulte et al., 2005).

\section{Confidence Interval}

Data will be collected through the distribution of the survey to a group of workers. Data collection through a survey is seldom done with entire populations but rather with samples drawn from a population. Even though we work with samples, our goal is to describe and draw inferences regarding the underlying population. It is possible to use a sample statistic and estimates of error in the sample to get a fair idea of the population parameter, not as a single value, but as a range of values. This range is the confidence interval $(\mathrm{Cl})$ which is estimated based on the desired confidence level.

Formulas for calculating Cls take the general form:

$\mathrm{Cl}=$ Point estimate \pm Margin of error Point estimate \pm Critical value $(z) \times$ Standard error of point estimate

$$
p \pm z \text { value } \times \sqrt{\left[p \frac{(1-p)}{n}\right]}
$$

The $\mathrm{Cl}$ of a statistic may be regarded as a range of values, calculated from sample observations, that is likely to contain the true population value with some degree of uncertainty. Although the $\mathrm{Cl}$ provides an estimate of the unknown population parameter, the interval computed from a particular sample does not necessarily include the true value of the parameter. Therefore, $\mathrm{Cls}$ are constructed at a confidence level, say $95 \%$, selected by the user. This implies that were the estimation process to be repeated over and over with random samples from the same population, then $95 \%$ of the calculated intervals would be expected to contain the true value. Calculation of the $\mathrm{Cl}$ of a sample statistic takes the general form: $\mathrm{Cl}$ $=$ Point estimate \pm Margin of error, where the margin of error is given by the product of a critical value $(\mathrm{z})$ derived from the standard normal curve and the standard error of point estimate.

The factors influencing the width of the $\mathrm{Cl}$ include the desired confidence level, the sample size, and the variability in the sample. Although the $95 \% \mathrm{Cl}$ is most often used, a $\mathrm{Cl}$ can be calculated for any level of confidence. A $99 \% \mathrm{Cl}$ will be wider than a $95 \% \mathrm{Cl}$ for the same 
sample. Table 2 indicates how the required sample size for population surveys varies with an acceptable margin of error and confidence level.

Table 2: Sample size required for surveys

\begin{tabular}{|c|c|c|c|c|c|c|}
\hline \multirow{3}{*}{$\begin{array}{l}\text { Estimated } \\
\text { population size }\end{array}$} & \multicolumn{6}{|c|}{ Margin of error } \\
\hline & \multicolumn{3}{|c|}{ Confidence level 95\% } & \multicolumn{3}{|c|}{ Confidence level 99\% } \\
\hline & $5 \%$ & $2.5 \%$ & $1 \%$ & $5 \%$ & $2.5 \%$ & $1 \%$ \\
\hline 100 & 80 & 94 & 99 & 87 & 96 & 99 \\
\hline 500 & 217 & 377 & 475 & 285 & 421 & 485 \\
\hline 1,000 & 278 & 606 & 906 & 399 & 727 & 943 \\
\hline 10,000 & 370 & 1332 & 4899 & 622 & 2098 & 6239 \\
\hline 100,000 & 383 & 1513 & 8762 & 659 & 2585 & 14227 \\
\hline 500,000 & 384 & 1532 & 9423 & 663 & 2640 & 16055 \\
\hline $1,000,000$ & 384 & 1534 & 9512 & 663 & 2647 & 16317 \\
\hline
\end{tabular}

The sample size is larger for a lower margin of error or higher level of confidence. Once the estimated population size is very large $(>100,000)$, the sample size is not changing much.

\section{Conclusion}

Following the successful outcome from a pilot project which tested 88 contractor workers, a minor adjustment was made to the questionnaire, next step of this exercise is to go for fullscale data collection to achieve a minimum of $95 \%$ data reliability to get the full picture and right data representation. The outcome from this data collection will help this research to achieve its objective in developing an assessment tool for contractor workers in the onshore oil and gas industry in Borneo/Tropics. Having this assessment tool will help the organization to have a competent workforce in terms of HSE, reduce the number of incidences, improving their HSE performance, and translated into good productivity.

\section{References}

Ahmadi, M., Cherqui, F., De Massiac, J.-C., \& Le Gauffre, P. (2014). Benefits of using basic, imprecise or uncertain data for elaborating sewer inspection programmes. In Structure and Infrastructure Engineering (Vol. 11, Issue 3, pp. 376-388). Informa UK Limited. https://doi.org/10.1080/15732479.2014.887122

Ahn, S., Lee, S., \& Steel, R. P. (2014). Construction Workers' Perceptions and Attitudes toward Social Norms as Predictors of Their Absence Behavior. In Journal of Construction Engineering and Management (Vol. 140, Issue 5, p. 04013069). American Society of Civil Engineers (ASCE). https://doi.org/10.1061/(asce)co.1943-7862.0000826

Andersson, I.-M., Gunnarsson, K., \& Rosèn, G. (2015). Role of Headmasters, Teachers, and Supervisors in Knowledge Transfer about Occupational Health and Safety to Pupils in Vocational Education. In Safety and Health at Work (Vol. 6, Issue 4, pp. 317-323). Elsevier BV. https://doi.org/10.1016/j.shaw.2015.07.012

Bayram, M. (2019). Safety Training and Competence, Employee Participation and Involvement, Employee Satisfaction, and Safety Performance: An Empirical Study On Occupational Health And Safety Management System Implementing Manufacturing Firms. Alphanumeric Journal, 7(2), 301-318. http://dx.doi.org/10.17093/alphanumeric.555154

Bena, A., Giraudo, M., Leombruni, R., \& Coasta, G. (2013) Job tenure and work injuries: a multivariate analysis of the relation with previous experience and differences by age. BMC Public Health 13, 869. https://doi.org/10.1186/1471-2458-13-869 
Bhusari, A., Goh, A., Ai, H., Sathanapally, S., Jalal, M., \& Mentzer, R. A. (2020). Process safety incidents across 14 industries. In Process Safety Progress (Vol. 40, Issue 1). Wiley. https://doi.org/10.1002/prs.12158

Breslin, F. C., Day, D., Tompa, E., Irvin, E., Bhattacharyya, S., Clarke, J., \& Wang, A. (2007). Nonagricultural work injuries among youth: a systematic review. American journal of preventive medicine, 32(2), 151-162. https://doi.org/10.1016/j.amepre.2006.10.007

Choudhry, R. M., Fang, D., \& Mohamed, S. (2007). The nature of safety culture: A survey of the state-of-the-art. In Safety Science (Vol. 45, Issue 10, pp. 993-1012). Elsevier BV. https://doi.org/10.1016/j.ssci.2006.09.003

Chung, J., Park, J., Cho, M., Park, Y., Kim, D., Yang, D., \& Yang, Y. (2015). A study on the relationships between age, work experience, cognition, and work ability in older employees working in heavy industry. In Journal of Physical Therapy Science (Vol. 27, Issue 1, pp. 155-157). Society of Physical Therapy Science.

https://doi.org/10.1589/jpts.27.155

Costa, P. T., \& McCrae, R. R. (1992) Normal Personality Assessment in Clinical Practice; The NEO Personality Inventory. Psychological Assessment. Vol. 4 (1); pp 5-13

Dingsdag, D. P., Biggs, H. C., \& Sheahan, V. L. (2008). Understanding and defining OH\&S competency for construction site positions: Worker perceptions. In Safety Science (Vol. 46, Issue 4, pp. 619-633). Elsevier BV. https://doi.org/10.1016/j.ssci.2007.06.008

Ferjencik, M., \& Slovackova, I. (2014). Trust managers and respect workmen: What does it mean to be competent in caring about safety? In Journal of Loss Prevention in the Process Industries (Vol. 32, pp. 95-108). Elsevier BV.

https://doi.org/10.1016/j.jlp.2014.08.001

Gallardo-Gallardo, E., Dries, N., \& González-Cruz, T. F. (2013). What is the meaning of 'talent' in the world of work? In Human Resource Management Review (Vol. 23, Issue 4, pp. 290-300). Elsevier BV. https://doi.org/10.1016/j.hrmr.2013.05.002

Guldenmund, F., Hale, A., Goossens, L., Betten, J., \& Duijm, N. J. (2006). The development of an audit technique to assess the quality of safety barrier management. Journal of hazardous materials, 130(3), 234-241. https://doi.org/10.1016/j.jhazmat.2005.07.011

Held, M. L., Black, D. R., Chaffin, K. M., Mallory, K. C., Diehl, M. A., \& Cummings, S. (2019). Training the Future Workforce: Social Workers in Integrated Health Care Settings. In Journal of Social Work Education (Vol. 55, Issue 1, pp. 50-63). Informa UK Limited. https://doi.org/10.1080/10437797.2018.1526728

Ismail, K., Nopiah, M. Z., Sattar, R., Mohamad \& Leong, P. C. (2020) Technical Competency among Vocational Teachers in Malaysian Public Skills Training Institutions: Measurement Model Validation Using PLS-SEM. Journal of Technical Education and Training. Vol. 12 (1), pp. 163-175

Kanason, E. (2018). 4 Key HR Challenges in the Oil and Gas Industry, OilVoice. https://oilvoice.com/Opinion/19935/4-Key-HR-Challenges-in-the-Oil-and-Gas-Industry

Kenayathulla, H. B., Ahmad, N. A., \& Idris, A. R. (2019). Gaps between competence and importance of employability skills: evidence from Malaysia. In Higher Education Evaluation and Development (Vol. 13, Issue 2, pp. 97-112). Emerald. https://doi.org/10.1108/heed-08-2019-0039.

Khan, A., Masrek, M. N., \& Nadzar, F. M. (2015). Analysis of competencies, job satisfaction and organizational commitment as indicators of job performance: A conceptual framework [JB]. Education for Information, 31(3), 125-141.

https://doi.org/10.3233/EFI-150954 
Kincl, L. D., Anton, D., Hess, J. A., \& Weeks, D. L. (2016). Safety voice for ergonomics (SAVE) project: protocol for a workplace cluster-randomized controlled trial to reduce musculoskeletal disorders in masonry apprentices. In BMC Public Health (Vol. 16, Issue 1). Springer Science and Business Media LLC. https://doi.org/10.1186/s12889-0162989-x

Laflamme, L., \& Menckel, E. (1995). Aging and occupational accidents a review of the literature of the last three decades. In Safety Science (Vol. 21, Issue 2, pp. 145-161). Elsevier BV. https://doi.org/10.1016/0925-7535(95)00059-3

Langford, D., Rowlinson, S., \& Sawacha, E. (2000). Safety behaviour and safety management: its influence on the attitudes of workers in the UK construction industry. In Engineering, Construction and Architectural Management (Vol. 7, Issue 2, pp. 133-140). Emerald. https://doi.org/10.1108/eb021138

Liu, S., Nkrumah, E. N. K., Akoto, L. S., Gyabeng, E., \& Nkrumah, E. (2020). The State of Occupational Health and Safety Management Frameworks (OHSMF) and Occupational Injuries and Accidents in the Ghanaian Oil and Gas Industry: Assessing the Mediating Role of Safety Knowledge. In BioMed Research International (Vol. 2020, pp. 1-14). Hindawi Limited. https://doi.org/10.1155/2020/6354895

Maddin, K., \& Shanks, D. A. (2016). Adapting Safety Culture Assessments to the Pipeline Industry. In Volume 2: Pipeline Safety Management Systems; Project Management, Design, Construction and Environmental Issues; Strain Based Design; Risk and Reliability; Northern Offshore and Production Pipelines. 2016 11th International Pipeline Conference. American Society of Mechanical Engineers.

https://doi.org/10.1115/ipc2016-64554

Mannan, S., \& Lees, F. P. (2012). Lees loss prevention in the process industries hazard identification, assessment, and control. Boston: Butterworth-Heinemann.

Mullen, J. (2004). Investigating factors that influence individual safety behavior at work. Journal of safety research, 35(3), 275-285. https://doi.org/10.1016/j.jsr.2004.03.011

Novianti, N., \& Nurlaelawati, I. (2019). Pedagogical Competence Development Of University Teachers With Non-Education Background: The Case Of Large University In Indonesia. In International Journal of Education (Vol. 11, Issue 2, p. 172). Universitas Pendidikan Indonesia (UPI). https://doi.org/10.17509/ije.v11i2.15711

Nykänen, M., Sund, R., \& Vuori, J. (2018). Enhancing safety competencies of young adults: A randomized field trial (RCT). Journal of safety research, 67, 45-56.

https://doi.org/10.1016/j.jsr.2018.09.012

Papazoglou, I. A., \& Aneziris, O. (1999). On the quantification of the effects of organizational and management factors in chemical installations. Reliability Engineering \& System Safety, 63(1), 33-45.

Pidgeon, N. F. (1991). Safety Culture and Risk Management in Organizations. In Journal of Cross-Cultural Psychology (Vol. 22, Issue 1, pp. 129-140). SAGE Publications. https://doi.org/10.1177/0022022191221009

Reyna, V. F., \& Farley, F. (2006). Risk and Rationality in Adolescent Decision Making. In Psychological Science in the Public Interest (Vol. 7, Issue 1, pp. 1-44). SAGE Publications. https://doi.org/10.1111/j.1529-1006.2006.00026.x

Russo, D. (2016). Competency Measurement Model. European Conference on Quality in Official Statistics, 1-29.

Ruzana, I., Azri, M. B., \& Hamizah, N. H. (2017). Offshore Safety Awareness Training System.Malaysian Journal of Public Health Medicine, Special Vol. 1: pp. 106-114 
Salminen S. (2004). Have young workers more injuries than older ones? An international literature reviews. Journal of safety research, 35(5), 513-521.

https://doi.org/10.1016/j.jsr.2004.08.005

Salminen, S., \& Palukka, P. (2007). Occupational safety training in the Finnish education system. Journal of Occupational Health and Safety, Australia and New Zealand, 23(4), 383-389.

Salthouse, T. A. (1997): Implications of adult age differences in cognition for work performance. Arbete Och Halsa Vetenskaplig Skriftserie, 45: 15-28.

Schulte, P. A., Stephenson, C. M., Okun, A. H., Palassis, J., \& Biddle, E. (2005). Integrating Occupational Safety and Health Information into Vocational and Technical Education and Other Workforce Preparation Programs. In American Journal of Public Health (Vol. 95, Issue 3, pp. 404-411). American Public Health Association.

https://doi.org/10.2105/ajph.2004.047241

Seo, H.-C., Lee, Y.-S., Kim, J.-J., \& Jee, N.-Y. (2015). Analyzing safety behaviors of temporary construction workers using structural equation modeling. In Safety Science (Vol. 77, pp. 160-168). Elsevier BV. https://doi.org/10.1016/j.ssci.2015.03.010

Spear L. P. (2000). The adolescent brain and age-related behavioral manifestations. Neuroscience and biobehavioral reviews, 24(4), 417-463. https://doi.org/10.1016/s0149-7634(00)00014-2

Suhairom, N., Musta'amal, A. H., Amin, M. N. F., Kamin, Y., \& Abdul Wahid, N. H. (2019). Quality culinary workforce competencies for sustainable career development among culinary professionals. In International Journal of Hospitality Management (Vol. 81, pp. 205-220). Elsevier BV. https://doi.org/10.1016/j.ijhm.2019.04.010

Taber, K. S. (2017). The Use of Cronbach's Alpha When Developing and Reporting Research Instruments in Science Education. In Research in Science Education (Vol. 48, Issue 6, pp. 1273-1296). Springer Science and Business Media LLC. https://doi.org/10.1007/s11165-016-9602-2

Tam, C. M., Zeng, S. X., \& Deng, Z. M. (2004). Identifying elements of poor construction safety management in China. In Safety Science (Vol. 42, Issue 7, pp. 569-586). Elsevier BV. https://doi.org/10.1016/j.ssci.2003.09.001

Tucker, S., \& Turner, N. (2013). Waiting for safety: Responses by young Canadian workers to unsafe work. In Journal of Safety Research (Vol. 45, pp. 103-110). Elsevier BV. https://doi.org/10.1016/j.jsr.2013.01.006

Vredenburgh, A. G. (2002). Organizational safety: which management practices are most effective in reducing employee injury rates? Journal of safety research, 33(2), 259-276.

Westaby, J. D., \& Lowe, J. K. (2005). Risk-taking orientation and injury among youth workers: examining the social influence of supervisors, coworkers, and parents. The Journal of applied psychology, 90(5), 1027-1035. https://doi.org/10.1037/0021-9010.90.5.1027

Wisner, A. (1984) Organization transfer towards industrially developing countries. In: Hendrick, J., Brown, O., Jr. (Eds.), Human Factors in Organizational Design and Management, North-Holland, Amsterdam, 467-478.

Zakocs, R. C., Runyan, C. W., Schulman, M. D., Dunn, K. A., \& Evensen, C. T. (1998). Improving safety for teens working in the retail trade sector: opportunities and obstacles. American journal of industrial medicine, 34(4), 342-350.

https://doi.org/10.1002/(sici)1097-0274(199810)34:4<342::aid-ajim7>3.0.co;2-u. 